\title{
Sorption and leaching characteristics of pesticides in volcanic ash soils of Jeju Island, Korea
}

\author{
Won-Pyo Park ${ }^{1}$ Kong-Man Chang ${ }^{2}$, Hae-Nam Hyun ${ }^{1}$, Kyung-Hwan Boo ${ }^{3,4^{*}}$ and Bon-Jun Koo ${ }^{5^{*}}$ (D)
}

\begin{abstract}
It is important to evaluate leaching behavior in agricultural soils to prevent the pollution of groundwater by pesticides. We identified the distribution coefficients $\left(K_{d}\right)$ of ten pesticides with different physicochemical properties and compared their leaching characteristics using wick lysimeters from three distinct soil types on Jeju Island. The $K_{d}$ values varied by pesticide and soil, but were within the range of 1.2 to $4231 \mathrm{~L} \mathrm{~kg}^{-1}$. Based on the European standard $\left(\mathrm{K}_{\mathrm{d}}<10 \mathrm{~L} \mathrm{~kg}^{-1}\right)$, six pesticides (alachlor, ethoprophos, carbofuran, napropamide, tebuconazole, and etridiazole) were mobile in at least one tested soil, and their soil organic carbon affinity was $\leq 5.811$. This value differed greatly from the other pesticides (16.533 and higher). The solubility of the six mobile pesticides was $\geq 32 \mathrm{mg} \mathrm{L}^{-1}$, which substantially differed from the other pesticides $\left(\leq 0.71 \mathrm{mg} \mathrm{L}^{-1}\right)$. Thus, we conclude that our mobility assessment, which is based on $\mathrm{K}_{\mathrm{d}}$ values, can be used to predict the leaching of pesticides in the volcanic ash soils of Jeju Island. The use of pesticides should be strictly controlled to reduce the possibility of groundwater contamination.
\end{abstract}

Keywords: Distribution coefficient, Leaching potential, Lysimeter, Organic carbon content, Pesticides, Volcanic ash soils

\section{Introduction}

Pesticides released into the soil undergo volatilization, absorption by plants, sorption, and decomposition within the soil. Leaching occurs when pesticides that have not been adsorbed or decomposed during the process of moving through the soil, flow downwards into lower soil layers with percolating water. As the pesticides leached from the soil move through the rock layer, they are likely to cause groundwater pollution if relevant filtration processes are absent [1]. To prevent the pollution of groundwater by pesticides, evaluating their leaching behavior in agricultural soils is important. There are increased

\footnotetext{
*Correspondence: khboo@jejunu.ac.kr; bonjunkoo@calbaptist.edu

${ }^{3}$ Department of Biotechnology, College of Applied Life Science (SARI),

Jeju National University, Jeju 63243, Republic of Korea

${ }^{5}$ Department of Biological Sciences, California Baptist University,

Riverside, CA 92504-3297, USA

Full list of author information is available at the end of the article
}

concerns about groundwater pollution caused by pesticides in islands.

The mean annual precipitation of Jeju Island, Korea is approximately $2000 \mathrm{~mm}$, which is greater than inland areas of Korea. Due to the characteristics of the volcanic geographical features of the island, at least $40 \%$ of the rainfall flows into the groundwater [2]. Further, an annual average of approximately 10,000 tons of pesticides has been applied on Jeju Island since 2000 [3]. Pesticide application time coincides with the heaviest rainfall period and as a result, there is a high possibility that the pesticides will reach the groundwater. The use of pesticides is unavoidable, so evaluating the probability for pesticides to flow into the groundwater and developing standards is necessary. Since groundwater pollution caused by pesticides are mainly dependent on soil characteristics, understanding the leaching behavior of pesticides in soils is required to regulate the use of pesticides for preventing groundwater pollution in Jeju Island. 
During the leaching of pesticides, the rate of sorption varies with soil characteristics (e.g., organic matter content within the soil and $\mathrm{pH}$ ) and pesticide characteristics (e.g., solubility and vapor pressure). The sorption equilibrium of pesticides is the most critical information to aid in understanding the concentration of pesticides that can be accommodated by variable organic matter contents of volcanic ash soils in Jeju Island. Linear and Freundlich equations are frequently used for evaluation, and the Freundlich equation demonstrated a higher correlation of coefficient values in the volcanic ash soils of Jeju Island $[4,5]$.

The distribution coefficient $\left(\mathrm{K}_{\mathrm{d}}\right)$ is a value indicating the proportion of pesticides distributed on the soil mineral phase and in the solution, thus, the $K_{d}$ values increases as the amount of sorption increases [6]. Soil texture and structure, organic matter, depth to groundwater, geology, temperature, light, moisture, bacteria, soil $\mathrm{pH}$, etc., all affect the principal process of pesticides occurring in the environment. Sorption of pesticides is affected by the properties of the pesticide, including the solubility and ionization of the pesticide, and the physicochemical properties of the soil. Among soil characteristics, soil $\mathrm{pH}$, clay content (soil charges), and organic carbon content are the most important factors affecting the sorption of pesticides. Soil $\mathrm{pH}$ and clay content are involved in sorption of ionic pesticides, and organic carbon content is primarily involved in sorption of nonionic pesticides $[4,5,7]$. The $K_{d}$ values is used as a basic parameter to investigate the possibility of applied pesticides not being sorbed into the soil and to predict the mobility of pesticides into groundwater [7-9]. The mobility of pesticides is determined by a $K_{d}$ cutoff value, below which pesticides are deemed mobile. This cutoff value is $5 \mathrm{~L} \mathrm{~kg}^{-1}$ in the United States of America (USA) and 10 $\mathrm{L} \mathrm{kg}^{-1}$ in Europe (Germany, Denmark, and the Netherlands) [10]. The cutoff values must be used depending on the properties of soils, such as the organic carbon content and $\mathrm{pH}$ of the soil, and the solubility of the pesticide. Organic carbon content of the soil and the solubility of the pesticides have the strongest influence on the $\mathrm{K}_{\mathrm{d}}$ values. The volcanic ash soils of Jeju Island generally have high organic carbon content, although it can vary widely depending on soil type. Therefore, the combination of $\mathrm{K}_{\mathrm{d}}$ values with soil organic carbon content of Jeju Island can be used to predict pesticide leaching.

Studies on the leaching characteristics of pesticides on farmlands have predominantly used lysimeters, which were first implemented approximately 300 years ago [11]. Wick and pan lysimeters have most commonly been used for recent pesticide leaching experiments. Francaviglia et al. [12] suggested experimental guidelines for lysimeter studies. Selecting appropriate lysimeters is critical for pesticide leaching experiments under natural soil conditions. Zhu et al. [13] reported that the recovery rate of the wick lysimeter was over double of the rate for the pan lysimeter. Schmidt and Lin [14] indicated an excellent recovery rate of the wick lysimeter following measurements for the recovery rate of bromide. In addition, the permeability coefficient of the soils used with the wick lysimeter was identical to the soils from the sampling area, which demonstrates the possibility to conduct an experiment using the same conditions as a natural soil in a given study area [15-17]. We therefore used the wick lysimeter to predict leaching characteristics in our study based upon favorable results from previous studies.

Previous studies on the leaching potential of pesticides on Jeju Island have used indices (e.g., groundwater ubiquity score, retardation factor, and attenuation factor) that are based on the physicochemical properties of the soil and the sorption properties of pesticides [18, 19]. Hyun et al. [19] evaluated the possibility of groundwater contamination of specific pesticides in volcanic ash soil in Jeju Island using the Groundwater Ubiquity Score (GUS). They classified pesticides with a GUS > 2.8 (GUS index is a leacher) such as alachlor, metolachlor, bromacil, ethoprophos, carbofuran, and metalaxyl as groundwater contaminants. These pesticides had a $K_{d}$ value of $5 \mathrm{~L} \mathrm{~kg}^{-1}$ or less and their solubility was high from 200 to $8400 \mathrm{mg} \mathrm{L}^{-1}$. Contrarily, in Hawaii volcanic ash soil, the transport of selected pesticides was predicted with the GUS values and the leaching of pesticides was studied [20]. In this result, it was predicted that the fungicide trifloxystrobin would not be leached with GUS $<1.8$ (GUS index is a nonleacher). However, trifloxystrobin was the most mobile pesticide among the pesticide tested in field leaching test. The results suggested that the prediction of pesticide leaching at the laboratory lever using GUS values might not be consistent with leaching of pesticides in the actual field. However, an assessment to verify pesticide mobility using lysimeters has not been conducted until now in the volcanic ash soils of Jeju Island.

To bridge this gap, the present study calculated the $\mathrm{K}_{\mathrm{d}}$ values of ten pesticides (three fungicides, four insecticides and three herbicides) that vary in physicochemical properties from a three-soil series of representative volcanic ash soils in Jeju Island (Donghong, Jeju, and Pyungdae) that contain differing organic carbon content. Further, this study aimed to provide data that can predict the probability of groundwater inflow for local pesticides by investigating the leaching rate of each pesticide using a wick lysimeter, and identifying their $\mathrm{K}_{\mathrm{d}}$ values and leaching characteristics. 


\section{Materials and methods}

\section{Study area}

Jeju Island $\left(\mathrm{N} 33^{\circ} 06^{\prime}-34^{\circ} 00^{\prime}, \quad \mathrm{E} 126^{\circ} 08-126^{\circ} 58^{\prime}\right)$ was formed by volcanic activity that occurred between approximately $1.88 \mathrm{Ma}$ to the Holocene [21, 22]. The area is covered by pyroclastic materials and lava in layers released from the area's 360 monogenetic volcanoes and polygenetic composite volcanoes, including Hallasan Mountain (1950 m above sea level) [22]. The island has a mild oceanic climate, and the average annual temperature is $15{ }^{\circ} \mathrm{C}$ without any variation among areas. However, the average annual rainfall $(2082 \mathrm{~mm})$ exhibits considerable variations. Normally, as the elevation increases by $100 \mathrm{~m}$, the rainfall increases by 100 to $250 \mathrm{~mm}$. The average rainfall of the eastern and southern areas is $2000 \mathrm{~mm}$, whereas average precipitation is relatively lower in the western coastal areas $(1100 \mathrm{~mm})$ [23]. In addition, due to the high permeability of soils and rocks, there are no permanent streams or rivers. Thus, the majority of the drinking water, agricultural water and water for industries are supplied by groundwater [21, 23].

The major parent material of the soils of Jeju Island is basalt and some soils that originate from trachyte and trachytic andesite [24]. Andisols, which comprise $80 \%$ of the soils, are distributed within the central and southeastern parts of the island and are accompanied by heavy rainfall [25]. Alfisols and Mollisols are widely distributed throughout the western and northern coastal areas and the middle mountainous areas, and these are accompanied by relatively less rainfall. Inceptisols and Ultisols with andic characteristics are distributed in areas of high elevation [26, 27]. The soils of Jeju are classified by color: black soils, very dark brown soils, dark brown soils, and brown forest soils (Fig. 1) [25]. Most of the soils that are distributed among the lava terraces are used to cultivate farm products (e.g., tangerines, carrots, potatoes, and radish), and some soils are used as grasslands.

\section{Soil sampling and analysis of physical and chemical properties}

Soil samples from three types of soil (Donghong, Jeju, and Pyungdae) with varying properties, as detailed in the Jeju soil map [28] (Fig. 1), were collected from the top $0-20 \mathrm{~cm}$. As the presence of pesticides is expected in farmland soils, the soil samples were collected from non-farmlands with consideration for the study location's agricultural use and distribution areas. According to the Taxonomical Classification of Korean Soils [26], Donghong soil (dark brown) is classified as Mollic Paleudafls and is located near the Wondang Peak of

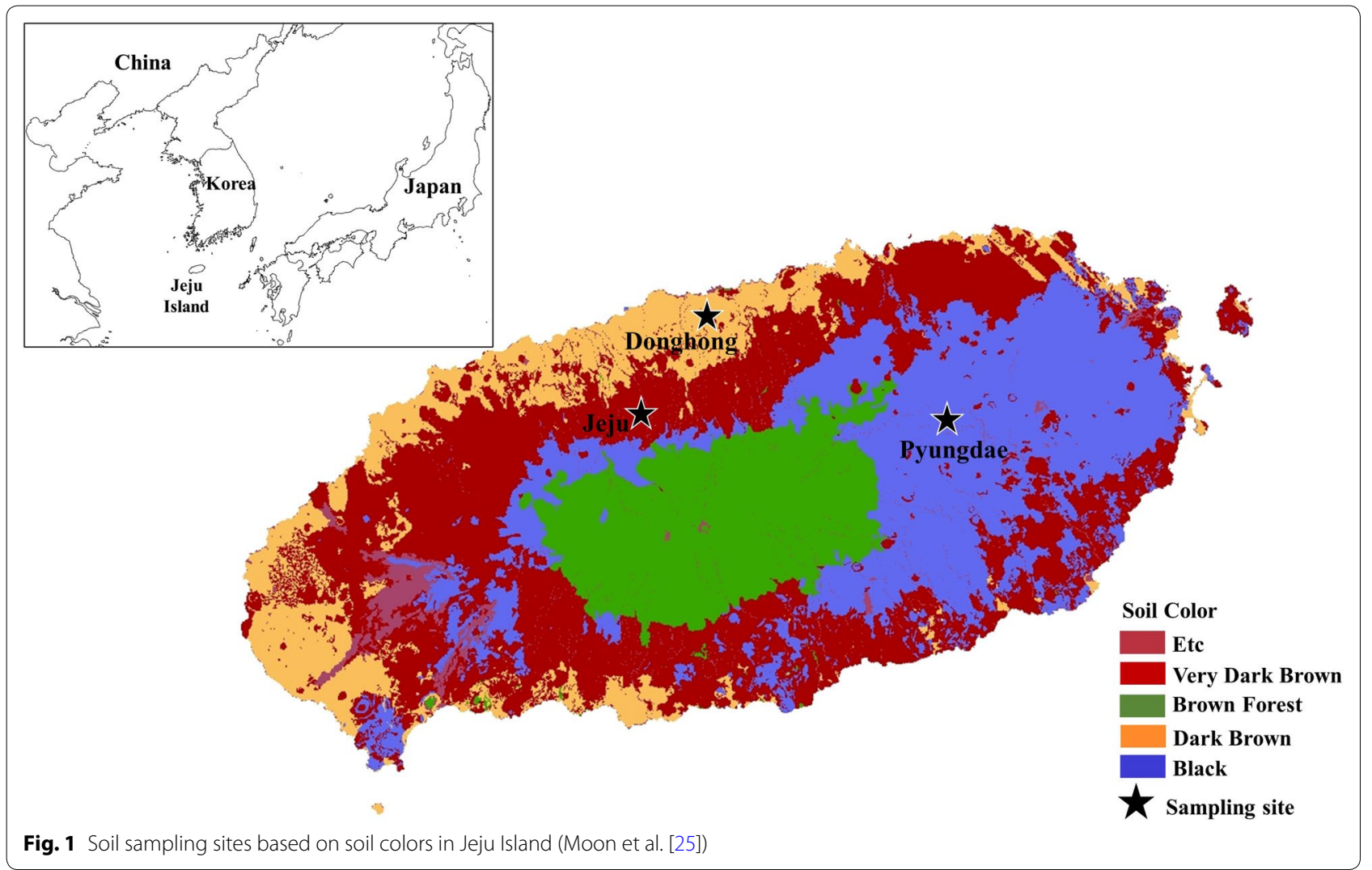


Jocheon-eup. Jeju soil (very dark brown) is classified as Andic Palehumults with a silt loam texture and is located in Haean-dong, Jeju-si. Pyungdae soil (black) is classified as Acrudoxic Melanudand with a silt loam texture and is located in Gyorae-ri, Jeju-si (Fig. 1). The collected soils were air-dried and sieved with a $2 \mathrm{~mm}$ sieve to analyze their physicochemical properties, sorption and leaching.

Among the chemical properties of the soil, we analyzed the $\mathrm{pH}$ and organic carbon contents. The $\mathrm{pH}$ of the soil was measured using an Orion Star A211 pH meter (Thermo Scientific, UK) with a 1:5 ratio of soil and distilled water. Organic carbon contents were analyzed using the Walkley and Black wet digestion method [29].

The following physical soil properties were analyzed: particle density, bulk density, porosity, and hydraulic conductivity. The particle density of the soil was measured using the pycnometer method [30], and the bulk density was measured by the core method [31]. Porosity was estimated through the particle and bulk density. The hydraulic conductivity was measured through the saturated hydraulic conductivity using the falling head method (Daiki, Japan) based on Darcy's law [32]. The saturated hydraulic conductivity is expressed in $\mathrm{m} \mathrm{d}^{-1}$.

\section{Pesticides}

The ten types of pesticides used in this study (fungicides: Etridiazole, Tebuconazole, and Tolclofos-methyl; insecticides: Carbofuran, Cypermethrin, Ethoprophos, and Fluazinam; and herbicides: Alachlor, Napropamide, and Pendimethalin) were randomly selected to test soil sorption and leaching. These pesticides vary in their physicochemical properties, including solubility, and are commonly used in citrus orchards and agricultural lands on Jeju Island. The pesticides were purchased from Chem Service (PA, USA) in technical grades. Their general physicochemical properties and IUPAC names are outlined in Table 1 [33].

\section{Simple evaluation of distribution coefficient}

To determine the distribution coefficient $\left(K_{d}\right)$ for the three soil series of representative volcanic ash soils in Jeju Island (Donghong, Jeju, and Pyungdae), we used single solution concentrations $\left(10 \mathrm{mg} \mathrm{L}^{-1}\right)$ of ten pesticides. The $K_{d}$ were simply calculated as the amount of adsorbed pesticide for single solution concentration $\left(10 \mathrm{mg} \mathrm{L}^{-1}\right)$ of the pesticides on the three soil series. They were calculated as $\mathrm{K}_{\mathrm{d}}\left(\mathrm{L} \mathrm{kg}^{-1}\right)=\mathrm{S} \mathrm{C}^{-1}$, where $\mathrm{S}$ is the concentration of pesticides adsorbed to the soil and $\mathrm{C}$ is the equilibrium concentration within the soil solution [19].

The stock solution was prepared by using methanol to obtain $1000 \mathrm{mg} \mathrm{L}^{-1}$. After we diluted the stock solution to obtain a $10 \mathrm{mg} \mathrm{L}^{-1}$ concentration for each pesticide, and this solution was prepared with water with $0.01 \mathrm{M}$ $\mathrm{CaCl}_{2}$ as a background electrolyte.

Sorption experiment was performed through the batch equilibration technique. Soil (5 g) and the pesticide solution $(25 \mathrm{~mL}$, soil: solution $=1: 5)$ were placed into a centrifuge tube, shaken at $200 \mathrm{rpm}$ for $24 \mathrm{~h}$ at $25{ }^{\circ} \mathrm{C}$, and then centrifuged for $30 \mathrm{~min}$ at $2500 \mathrm{rpm}$ to separate the soil and solution. About $0.2 \mathrm{~g}$ of $\mathrm{NaCl}$ was added to $5 \mathrm{~mL}$ of the supernatant of the centrifuged solution, and then $5 \mathrm{~mL}$ of a solvent in which hexane and ethyl acetate were mixed in a ratio of 1:1 was added, and the mixture was shaken vigorously for $1 \mathrm{~min}$. After the mixed solution settled for $30 \mathrm{~min}$, the components distributed to the organic solvents were analyzed through gas chromatography (GC) (Hewlett Packard, HP6890 Series II, USA). We used an Ultra-2 capillary column (Cross-linked 5\% phenyl methyl silicone, $25 \mathrm{~m} \times 0.32 \mathrm{~mm}$ ID $\times 0.52 \mathrm{uM}$ ) and either an electron capture detector (ECD) or nitrogen phosphorus detector (NPD) for GC analysis. In this condition, limit of detection (LOD) and limit of quantification (LOQ) of ten pesticides were $0.04-0.07 \mathrm{ng}$ and $0.13-0.23 \mathrm{ug} \mathrm{mL}^{-1}$, respectively. The correlation coefficients $\left(R^{2}\right)$ of linearity ranged from 0.9784 to 0.9999 .

When calculating the amount of adsorbed pesticide, we considered that the pesticide was adsorbed to the soil, excluding the residual of the supernatant. We performed QA/QC for the GC determination and a blank soil used as matrix. The standard calibration curve was prepared by using four standard solutions with different concentrations $\left(1,2.5,5\right.$, and $\left.10 \mathrm{~m} \mathrm{~L}^{-1}\right)$ and then performed the same method as the sample analysis for the blank test without adding soil.

\section{Soil organic carbon affinity of pesticide}

Soil organic carbon affinity (SOCA, the relationship between the organic carbon content of the soil and the $K_{d}$ of pesticides) of pesticides can be a major factor for the sorption of pesticides in soils with varying organic content in Jeju Island soil. Therefore, in this study, the SOCA of each pesticide was calculated as the slope of the regression equation through simple linear regression analysis of the relationship between the $K_{d}$ value of each pesticide and the organic carbon content of the soil.

\section{Lysimeter construction}

The lysimeter experimental area was created within a vinyl greenhouse, where wind and sunlight can naturally enter, and rainfall is artificially controlled. To create the lysimeter experimental area, a basic framework to install the lysimeter was constructed, and the lysimeter was secured after adjusting its level. A wick lysimeter was used with a dimension of $30 \times 30 \times 5 \mathrm{~cm}$ (width $\times$ length $\times$ depth) in this experiment as 
Table 1 IUPAC names and properties of the pesticides used in this study

\begin{tabular}{|c|c|c|c|c|c|c|}
\hline Pesticide & $\begin{array}{l}\text { IUPAC } \\
\text { name }\end{array}$ & Chemical structure & $\begin{array}{c}\mathrm{K}_{\mathrm{ow}} \\
(\log \mathrm{P})\end{array}$ & $\begin{array}{c}\text { Water } \\
\text { solubility } \\
\left(\mathrm{mg} \mathrm{L}^{-1}\right)\end{array}$ & $\begin{array}{c}\text { Soil } \\
\text { half-life } \\
\text { (days) }\end{array}$ & $\begin{array}{l}\text { Vapor } \\
\text { pressure } \\
(\mathrm{mPa})\end{array}$ \\
\hline Etridiazole & $\begin{array}{l}\text { ethyl 3-trichloromethyl-1,2,4- } \\
\text { thiadiazol-5-yl ether }\end{array}$ & & 3.37 & 88.9 & 20 & 1430 \\
\hline Tebuconazole & $\begin{array}{l}\text { (RS)-1-p-chlorophenyl- } \\
\text { 4,4-dimethyl-3-(1H-1,2,4- } \\
\text { triazol-1-ylmethyl)pentan- } \\
\text { 3-ol }\end{array}$ & & 3.7 & 36 & 63 & 0.0013 \\
\hline $\begin{array}{l}\text { Tolclofos- } \\
\text { methyl }\end{array}$ & $\begin{array}{l}\text { O-2,6-dichloro-p-tolyl } \\
\text { O,O-dimethyl } \\
\text { phosphorothioate }\end{array}$ & & 3.8 & 0.708 & 7.6 & 0.877 \\
\hline Carbofuran & $\begin{array}{l}\text { 2,3-dihydro-2,2- } \\
\text { dimethylbenzofuran-7-yl } \\
\text { methylcarbamate }\end{array}$ & & 1.8 & 322 & 29 & 0.08 \\
\hline Cypermethrin & $\begin{array}{c}\text { (RS)- } \alpha \text {-cyano-3- } \\
\text { phenoxybenzyl } \\
\text { (1RS,3RS;1RS,3SR)-3- } \\
\text { (2,2-dichlorovinyl)-2,2- } \\
\text { dimethylcyclopropanecar } \\
\text { boxylate }\end{array}$ & & 5.55 & 0.009 & 22.1 & 0.0068 \\
\hline Ethoprophos & $\begin{array}{l}O \text {-ethylS,S-dipropyl } \\
\text { phosphorodithioate }\end{array}$ & & 2.99 & 1300 & 13.6 & 78.0 \\
\hline Fluazinam & $\begin{array}{l}\text { 3-chloro-N-(3-chloro-5- } \\
\text { trifluoromethyl-2- } \\
\text { pyridyl)- } \alpha, \alpha, \alpha \text {-trifluoro- } \\
\text { 2,6-dinitro-p-toluidine }\end{array}$ & & 4.87 & 0.135 & 25.9 & 0.0172 \\
\hline Alachlor & $\begin{array}{l}\text { 2-chloro-2',6'-diethyl-N- } \\
\text { methoxymethylacetanilide }\end{array}$ & $\mathrm{CH}_{3}$ & 3.09 & 240 & 14 & 2.9 \\
\hline Napropamide & $\begin{array}{l}\text { (RS)-N,N-diethyl-2-(1- } \\
\text { naphthyloxy)propionamide }\end{array}$ & $\operatorname{CON}\left(\mathrm{CH}_{2} \mathrm{CH}_{3}\right)_{2}$ & 3.3 & 74 & 70 & 0.022 \\
\hline Pendimethalin & $\begin{array}{l}\text { N-(1-ethylpropyl)-2,6- } \\
\text { dinitro-3,4-xylidine }\end{array}$ & & 5.4 & 0.33 & 182.3 & 3.34 \\
\hline
\end{tabular}

described in Fig. 2 [13, 14]. A tube for the fiberglass wick ( $2 \mathrm{~cm}$ i.d.) was used to improve the recovery efficiency, and the length of the wick within the lysimeter was set to $30 \mathrm{~cm}$ to maintain natural soil conditions [14]. On top of the secured lysimeter, a round plastic container ( $80 \mathrm{~cm}$ i.d.) was used to fill the soil to ensure that the lysimeter was at the center of the container. The lysimeter was filled with the three types of soil after they passed through the $2.0 \mathrm{~mm}$ sieves, which removed any gravel. 


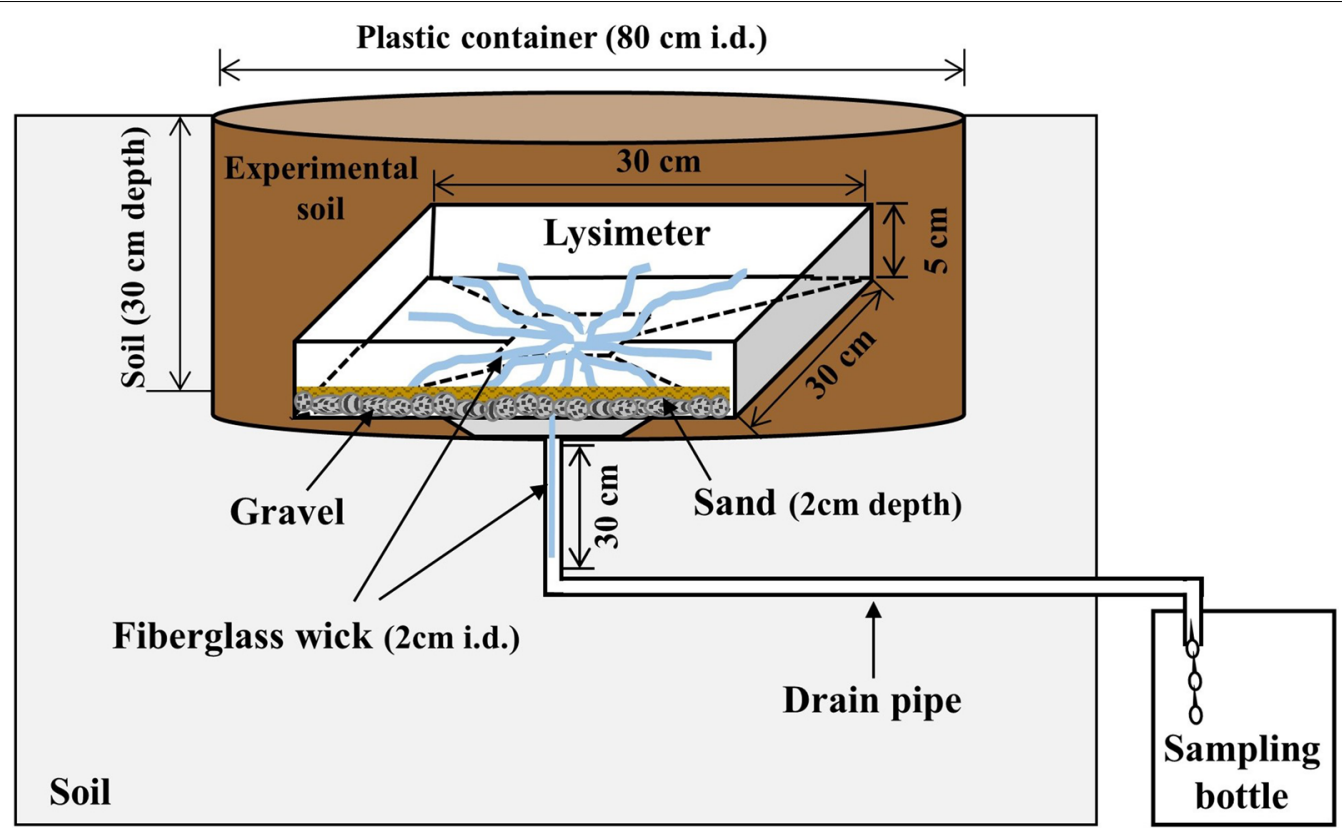

Fig. 2 Schematic design of the wick lysimeter

To fill the soil within the lysimeter, firstly, a water-sampling environment was created with round gravels from the coast that were not polluted with pesticides. A sand layer, $2 \mathrm{~cm}$ thick, covered the gravels, and each sand grain had a diameter of 0.06-2 $\mathrm{mm}$. The experimental soil was spread out in a thickness of approximately $1 \mathrm{~cm}$ to ensure that as much of wick of the glass fiber was exposed to the soil. Next, the experimental soils were filled to a depth of $30 \mathrm{~cm}$ (i.e., average soil depth on Jeju Island) and to verify whether the lysimeter was stabilized and operated correctly, 20-40 mm of artificial rain was supplied over a period of three to 5 days for a total of 60 days. During the stabilizing period, any lost soil was replenished in the experimental area. To confirm whether the soil was stabilized, the physical properties of the soil at the time of extraction (bulk density and porosity) and the end of the leaching experiment were compared. The test plot of the lysimeter consisted of three repeated trials for the three soils, and the locations of the test plots were decided through a completely randomized design.

\section{Tracer and pesticides treatment}

The lysimeter leaching experiment for the pesticides within the soil was performed through the bromide tracer method [34-36]. The treatment of the bromide was conducted with $100 \mathrm{~kg} \mathrm{ha}^{-1}$ based on $\mathrm{KBr}$ and $6.7 \mathrm{~g} \mathrm{~m}^{-2}$ of bromide. The lysimeters for the pesticides were treated with double the standard concentration, considering the actual application amount of the pesticides. The applied concentration levels are outlined in Table 2.

\section{Artificial rainfall and water received}

The artificial rainfall was derived from a small sprinkler during the process of soil stabilization to ensure identical rainfall levels for all experimental areas. There was an artificial rainfall event once every 7 days and this experimental design was conducted for 63 days (9 weeks), which represents the duration of heavy concentrated rainfall in the Jeju area. Leached water from the lysimeters was recovered for 3 days in a row following the artificial rainfall. The level of artificial rainfall, received water, and the recovery rate are shown in Table 3 . The average artificial rainfall was $45.7 \pm 2.1 \mathrm{~mm}$, and the average recovery rate was $81.1 \%$.

\section{Leached tracer and pesticides analysis}

The bromide leaching types, tracer, and pesticides were analyzed by identifying the leaching rate $\left(\mathrm{C} / \mathrm{C}_{0}\right.$, the proportion of detected $\mathrm{Br}^{-}$during the experiment or the proportion of the process concentration $\left(C_{0}\right)$ of each pesticide $(\mathrm{C})$ ), the pore volume $(\mathrm{PV})$, and accumulated leaching rates (\%)).

$\mathrm{Br}^{-}$was analyzed as a tracer through ion chromatography (Dionex DX-100, USA) after filtering the collected water sample and the standard solution with a $0.2 \mu \mathrm{m}$ cellulose acetate filter during each experiment.

To quantify the pesticides, $500 \mathrm{~mL}$ of the collected water samples of each experiment were analyzed with either GC-ECD or GC-NPD. The extraction and analysis conditions were identical to those employed in the sorption experiments of pesticides mentioned above. 


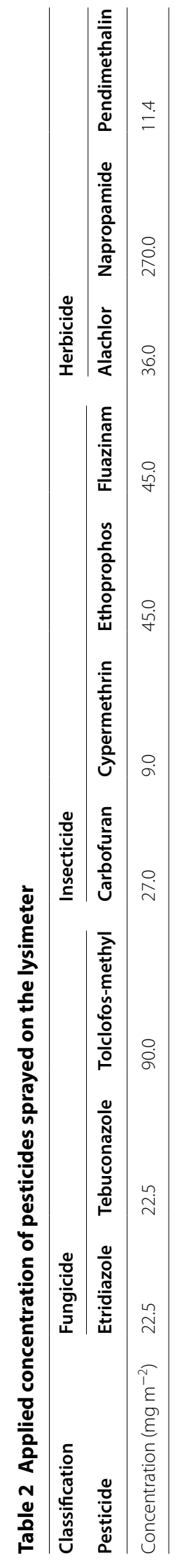


Table 3 Amount of artificial rainfall, received water, and recovery rate for each week

\begin{tabular}{llll}
\hline Weeks & Artificial rain $(\mathbf{m m})$ & $\begin{array}{l}\text { Received } \\
\text { amounts }(\mathbf{m L})\end{array}$ & Recovery (\%) \\
\hline 1 & $57.9 \pm 6.1$ & 4820 & 92.5 \\
2 & $45.5 \pm 2.7$ & 2811 & 68.6 \\
3 & $44.7 \pm 1.1$ & 2751 & 68.4 \\
4 & $46.6 \pm 2.2$ & 3691 & 88.0 \\
5 & $44.5 \pm 3.6$ & 3228 & 80.6 \\
6 & $41.1 \pm 1.1$ & 2773 & 75.0 \\
7 & $42.2 \pm 0.2$ & 3091 & 81.4 \\
8 & $49.1 \pm 6.2$ & 4182 & 94.6 \\
9 & $39.7 \pm 3.4$ & 3300 & 81.0 \\
Average & $45.7 \pm 2.1$ & 3405 & 81.1 \\
Total & 411.4 & & \\
\hline
\end{tabular}

\section{Results and discussion}

\section{Physical and chemical properties of soil samples}

The soil used for the sorption experiment varied in its physical and chemical properties (Table 4). The organic carbon contents differed strongly among the soils: Donghong soil (dark brown) had a carbon content of $14.8 \mathrm{~g} \mathrm{~kg}^{-1}$, Jeju soil (very dark brown) was $52.0 \mathrm{~g} \mathrm{~kg}^{-1}$, and Pyungdae soil (black) was $137.0 \mathrm{~g} \mathrm{~kg}^{-1}$. Among the physical properties, Donghong soil had the highest bulk density with $1.1 \mathrm{~g} \mathrm{~cm}^{-3}$, followed by Jeju soil and Pyungdae soil, but there was no great difference in the particle density. Pyungdae soil had the greatest porosity with $74.4 \%$, followed by Jeju soil (71.1\%) and Donghong soil (54.4\%). Pyungdae soil had the highest hydraulic conductivity at $0.059 \mathrm{~m} \mathrm{~d}^{-1}$, followed by Jeju soil $\left(0.036 \mathrm{~m} \mathrm{~d}^{-1}\right)$ and Donghong soil $\left(0.021 \mathrm{~m} \mathrm{~d}^{-1}\right)$.

As the soil color tends to be black on Jeju Island, there are higher amounts of organic carbon and fine sand. In addition, there is a higher porosity and lower bulk density, which leads to higher water permeability. In contrast, dark brown (Donghong) soil has a lower organic carbon content and higher bulk density, which results in lower water permeability. Very dark brown (Jeju) soil is between black (Pyungdae) soil and dark brown soil in terms of permeability [37]. On average, the organic carbon content was $16.2 \mathrm{~g} \mathrm{~kg}^{-1}$ for dark brown soil, $51.9 \mathrm{~g} \mathrm{~kg}^{-1}$ for very dark brown soil, and $100.1 \mathrm{~g} \mathrm{~kg}^{-1}$ for black soil. The average bulk density was $1.31 \mathrm{~g} \mathrm{~cm}^{-3}$ for dark brown soil, $0.98 \mathrm{~g} \mathrm{~cm}^{-3}$ for very dark brown soil, and $0.77 \mathrm{~g} \mathrm{~cm}^{-3}$ for black soil [37]. The results of the physicochemical properties for the three soils were similar to the commonly known properties of each soil. Therefore, these could be used as representative soils in our experiment.

\section{Mobility of pesticides based on the soil distribution coefficient}

The soil $K_{d}$ of the ten types of pesticides were calculated and their mobility was assessed by applying the European standard $\left(\mathrm{K}_{\mathrm{d}}<10 \mathrm{~L} \mathrm{~kg}^{-1}\right)$ (Table 5). Six pesticides (alachlor, ethoprophos, carbofuran, napropamide, tebuconazole, and etridiazole) were predicted to have mobility within at least one soil type, as the $\mathrm{K}_{\mathrm{d}}$ values were within the range from 1.24 to $9.33 \mathrm{~L} \mathrm{~kg}^{-1}$.

Based on the different types of the soils, the six pesticides were shown to be mobile within the Donghong soil that has the lowest organic carbon contents while three pesticides (alachlor, ethoprophos and carbofuran) were exposed to be mobile within the Jeju soil that has medium amounts of organic carbon content. Only one pesticide (alachlor) was shown to be mobile in the Pyungdae soil, which contains the greatest organic carbon content. Alachlor, which was predicted to be mobile in all study soils, had a similar $K_{d}$ value of $10 \mathrm{~L} \mathrm{~kg}^{-1}$ or less in Jeju soils as previous studies $[4,19]$. Also, Donghong soil had similar $\mathrm{K}_{\mathrm{d}}$ values (1.43-2.41\%) to Hawaiian soils (1.89-2.99 L $\mathrm{kg}^{-1}$ ) with a low organic carbon content [38]. However, the remaining four pesticides (cypermethrin, fluazinam, pendimethalin, and tolclofos-methyl) had $K_{d}$ values from 26.0 to $4231 \mathrm{~L} \mathrm{~kg}^{-1}$, which demonstrated no mobility in all studied soils.

The six pesticides that we predicted to be mobile and the remaining four pesticides demonstrated distinct

Table 4 Physical and chemical properties of the soil samples

\begin{tabular}{|c|c|c|c|c|c|c|c|c|c|}
\hline Soil series & $\begin{array}{l}\mathrm{PH} \\
(1: 5)\end{array}$ & $\begin{array}{l}\mathrm{OC} \\
\left(\mathrm{g} \mathrm{kg}^{-1}\right)\end{array}$ & $\begin{array}{l}\rho_{\mathrm{b}} \\
\left(\mathrm{g} \mathrm{cm}^{-3}\right)\end{array}$ & $\begin{array}{l}\rho_{\mathrm{p}} \\
\left(\mathrm{g} \mathrm{cm}^{-3}\right)\end{array}$ & $\begin{array}{l}\text { F } \\
(\%)\end{array}$ & $\begin{array}{l}\theta \\
\left(\mathrm{m}^{3} \mathrm{~m}^{-3}\right)\end{array}$ & $\begin{array}{l}\mathrm{Ks} \\
\left(\mathrm{m} \mathrm{d}^{-1}\right)\end{array}$ & Coordinates & Soil taxonomy \\
\hline Donghong & 4.7 & 14.8 & 1.1 & 2.5 & 54.4 & 0.40 & 0.021 & $\begin{array}{l}\mathrm{N} 33^{\circ} 31^{\prime} 24.7^{\prime \prime} \\
\mathrm{E} 126^{\circ} 36^{\prime} 16.3^{\prime \prime}\end{array}$ & Mollic Paleudafls \\
\hline Jeju & 4.9 & 52.0 & 0.7 & 2.5 & 71.1 & 0.41 & 0.036 & $\begin{array}{l}\mathrm{N} 33^{\circ} 26^{\prime} 08.6^{\prime \prime} \\
\mathrm{E} 126^{\circ} 28^{\prime} 24.1^{\prime \prime}\end{array}$ & Andic Palehumults \\
\hline Pyungdae & 6.0 & 137.0 & 0.6 & 2.4 & 74.4 & 0.43 & 0.059 & $\begin{array}{l}\text { N33 } 23^{\circ} 55.7^{\prime \prime} \\
\text { E126 } 42^{\prime} 37.8^{\prime \prime}\end{array}$ & Acrudoxic Melanudand \\
\hline
\end{tabular}

OC Organic carbon, $\rho_{b}$ Soil bulk density, $\rho_{p}$ Soil particle density, $f$ Porosity, $\theta$ Volumetric water content at field capacity, $K s$ Hydraulic conductivity 
Table 5 Distribution coefficients (mean \pm SD where $n=3$ ) of pesticides of the soil series of Donghong, Jeju, and Pyungdae

\begin{tabular}{|c|c|c|c|c|c|}
\hline Pesticide & $\begin{array}{l}\text { Donghong } \\
K_{d}\left(L k^{-1}\right)\end{array}$ & Jeju & Pyungdae & Linear regression $^{a}$ & $R^{2}$ \\
\hline Alachlor & $1.24 \pm 0.15$ & $3.50 \pm 0.38$ & $8.48 \pm 0.42$ & $Y=0.5912 x+0.3866$ & 0.9999 \\
\hline Ethoprophos & $1.80 \pm 0.45$ & $3.70 \pm 0.17$ & $10.5 \pm 2.88$ & $Y=0.7277 x+0.384$ & 0.9928 \\
\hline Carbofuran & $2.70 \pm 0.60$ & $4.87 \pm 0.17$ & $17.6 \pm 2.00$ & $Y=1.2694-0.2424$ & 0.9739 \\
\hline Napropamide & $4.68 \pm 1.72$ & $19.6 \pm 1.41$ & $47.2 \pm 4.10$ & $Y=3.4344 x+0.5136$ & 0.9983 \\
\hline Tebuconazole & $5.93 \pm 2.58$ & $19.5 \pm 3.41$ & $45.5 \pm 2.56$ & $Y=3.2082 x+1.8484$ & 0.9975 \\
\hline Etridiazole & $9.33 \pm 2.52$ & $23.5 \pm 2.60$ & $78.6 \pm 11.8$ & $Y=5.8111 x-2.3431$ & 0.9887 \\
\hline Tolclofos-methyl & $26.0 \pm 4.65$ & $68.6 \pm 2.10$ & $223 \pm 40.1$ & $Y=16.533 x-6.1989$ & 0.9909 \\
\hline Pendimethalin & $59.5 \pm 11.6$ & $193.0 \pm 24.7$ & $406 \pm 15.5$ & $Y=27.792 x+30.733$ & 0.9919 \\
\hline Fluazinam & $142 \pm 35.7$ & $456 \pm 41.6$ & $789 \pm 11.6$ & $Y=50.601 x+118.79$ & 0.9585 \\
\hline Cypermethrin & $790 \pm 121$ & $1523 \pm 301$ & $4231 \pm 392$ & $Y=287.97 x+225.08$ & 0.9905 \\
\hline
\end{tabular}

a Linear regressions for adsorption coefficients $\left(\mathrm{K}_{\mathrm{d}}\right)$ and organic carbon $\left(\mathrm{g} \mathrm{kg}^{-1}\right)$ of soils for each pesticide

differences in their leachability, soil organic carbon affinities (SOCA; the higher organic carbon contents, the higher $\mathrm{K}_{\mathrm{d}}$ values), and solubility (Table 5 , Additional file 1: Figs. S1 and S2). The SOCA of the six pesticides that were expected to be mobile were $\leq 5.81$, whereas the solubility values were $\geq 36.0 \mathrm{mg} \mathrm{L}^{-1}$. However, the four pesticides that were predicted to be immobile contained organic carbon affinities of $\geq 16.5$ and solubility rates of $\leq 1.0 \mathrm{mg} \mathrm{L}^{-1}$.

Based on these results, the $K_{d}$ that reflects the organic carbon affinities and solubility of the pesticides could be used as an important standard to assess the mobility of the pesticides. In the volcanic ash soils of Jeju Island, where organic carbon content varies by region, the prediction of the mobility of pesticides according to the SOCA will be very important for not only the soil environment but also for the management and prevention of groundwater pollution.

\section{Leaching behavior of the tracer}

Bromide from the lysimeter displayed a leaching peak after 4 to 5 weeks for the Donghong and Jeju soils. However, for the Pyungdae soil, bromide showed a leaching peak after 3 weeks (Fig. 3). When accumulated leaching reached $100 \%$, the pore volume (PV) of the Donghong soil was 2.00 PV, the Jeju soil was 1.65 PV, and the Pyungdae soil was $1.50 \mathrm{PV}$. Therefore, leaching from bromides occurred earliest within the Pyungdae soil, followed by the Jeju soil, and Donghong soil (Fig. 4).

Bromide commonly shows minimal sorption and moves at the same speed as water [34]. Therefore, the speed of bromide is closely related to hydraulic conductivity, and a greater hydraulic conductivity results in a faster speed. Kelly and Pomes [39] reported that a

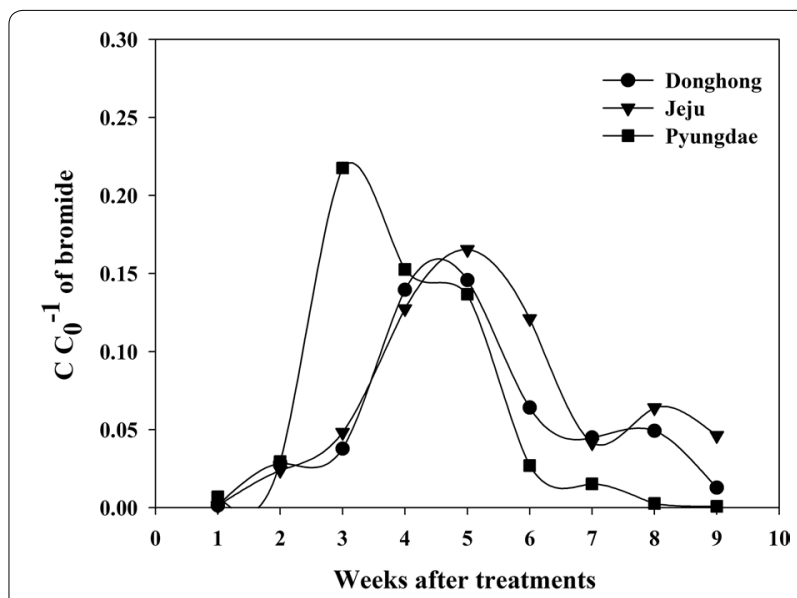

Fig. 3 Bromide leached fraction $\left(C / C_{0}\right)$ curves from lysimeters for the soil series of Donghong, Jeju, and Pyungdae over a nine-week period

faster hydraulic conductivity led to an earlier peak of bromide during the leaching of bromide. The lysimeter experiment by Piwowarczyk et al. [40] also confirmed that the leaching of bromide was faster in soils with greater hydraulic conductivity.

Identifying the relationship between the hydraulic conductivity and the movement of bromide in the three types of soil, we also demonstrate that a greater hydraulic conductivity leads to faster movement. Further, after comparing the relationship between the PV and hydraulic conductivity at the point of $50 \%$ bromide leaching (Fig. 5), the greater water permeability displayed an inverse proportion with the PV, coinciding with the leaching peak $\left(r^{2}=0.986\right)$. This is identical to the faster movement of bromide under a greater hydraulic conductivity in natural soils, which indicates 


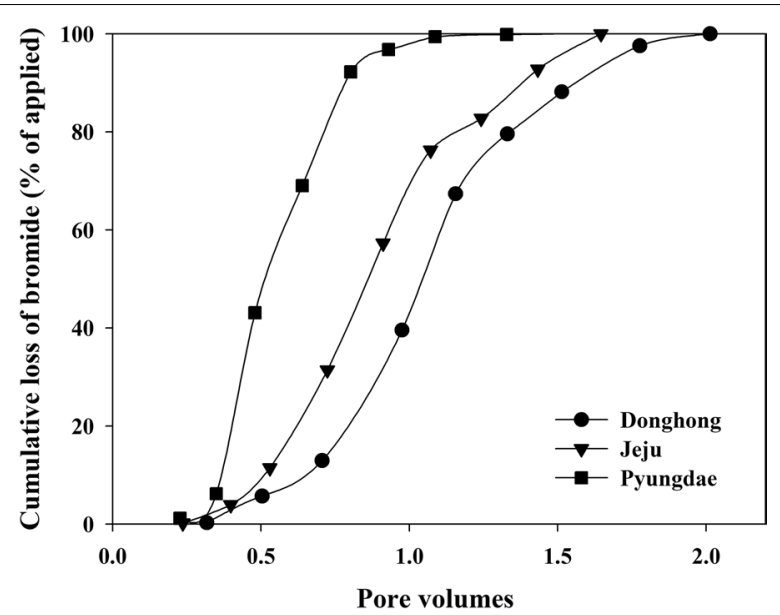

Fig. 4 Cumulative bromide leaching loss (\%) with pore volumes of the soil series of Donghong, Jeju, and Pyungdae over a nine-week period

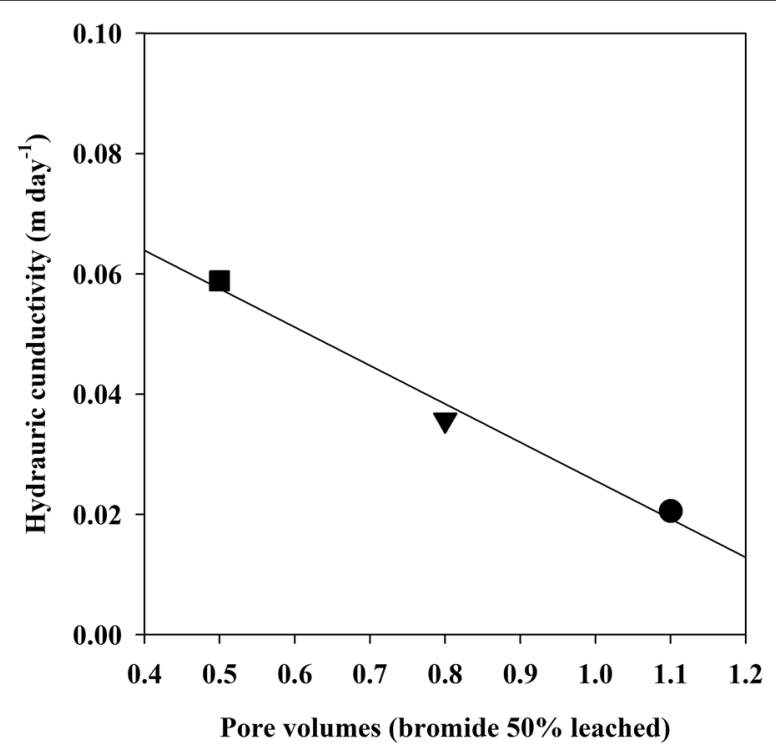

Fig. 5 Relationship between pore volume and hydraulic conductivity for the soil series of Donghong (Black circle), Jeju (Black down-pointing triangle), and Pyungdae (Black square) based on 50\% bromide leaching

that the lysimeters in this study efficiently matched the natural soil conditions of the extracted samples.

\section{Leaching behavior of pesticides}

We determined the leaching behavior of pesticides from a wick lysimeter with artificial rainfall once every 7 days for a total of 9 weeks. Among the six pesticides that were expected to be mobile based on the $\mathrm{K}_{\mathrm{d}}$ values, five pesticides (alachlor, carbofuran, ethoprophos, napropamide, and tebuconazole), excluding etridiazole, leached from at least one type of the experimental soil. However, the remaining five pesticides (cypermethrin, etridiazole, fluazinam, pendimethalin, and tolclofos-methyl) did not leach from any soil type during the experiment (Fig. 6).

All five pesticides (alachlor, carbofuran, ethoprophos, napropamide, and tebuconazole) leached from the Donghong soil. Only three pesticides (alachlor, ethoprophos, and carbofuran) leached from the Jeju soil, and only one pesticide (carbofuran) leached from the Pyungdae soil. This was consistent with the results of the mobility prediction based on the $K_{d}$ values. However, alachlor, which was expected to be mobile in the Pyungdae soil, did not leach, whereas carbofuran, which was not expected to be mobile, did leach. In addition, etridiazole, which was expected to be mobile in the Donghong soil, did not leach.

Among the five pesticides that leached, alachlor was expected to be mobile within all three types of soil. This is because its $K_{d}$ values was less than $10 \mathrm{~L} \mathrm{~kg}^{-1}$ and its SOCA was the lowest among all types of pesticides (0.59), thus, potentially resulting in the most efficient leaching rate of all soils. However, the lysimeter showed that although alachlor leached slightly from the Donghong and Jeju soils and it did not leach from the Pyungdae soil. Alachlor leached after 3 weeks from the Donghong soil and created a leaching peak of $6 \%$ after 5 weeks, then leached by $0.8 \%$ from the Jeju soil after 9 weeks. The accumulated leaching from the Donghong soil was $26.0 \%(2.00 \mathrm{PV})$ and was $1.82 \%(1.65 \mathrm{PV})$ the Jeju soil. These results correspond with previous studies reporting that alachlor is more easily leached from soils with lower organic carbon contents [41, 42].

Conversely, carbofuran was only expected to leach from the Donghong and Jeju soils due to their relatively lower organic carbon contents and based on their $\mathrm{K}_{\mathrm{d}}$ values. In contrast, carbofuran leached from all soil types in the Donghong soil, and leaching began after 1 week, reached an initial peak concentration of $10 \%$ after 4 to 5 weeks, and then decreased. In the Jeju soil, leaching began after 4 weeks and reached an initial peak concentration of $5 \%$ after 7 to 9 weeks. Finally, in the Pyungdae soil, carbofuran leached slightly after 7 weeks. The accumulated leaching from the Donghong soil was 39.1\% (2.00 PV), the Jeju soil was $16.1 \%$ (1.65 PV), and the Pyungdae soil was $0.34 \%(1.50 \mathrm{PV})$. The accumulated leaching from the Pyungdae soil was over 100 times lower than the Donghong soil. In addition, carbofuran exhibited the highest leaching rate among all leaching pesticides in this study.

The other three pesticides (ethoprophos, napropamide, tebuconazole) that leached recorded the same results predicted by the $K_{d}$ values. Although ethoprophos demonstrated the highest solubility $\left(1300 \mathrm{mg} \mathrm{L}^{-1}\right)$ among the 

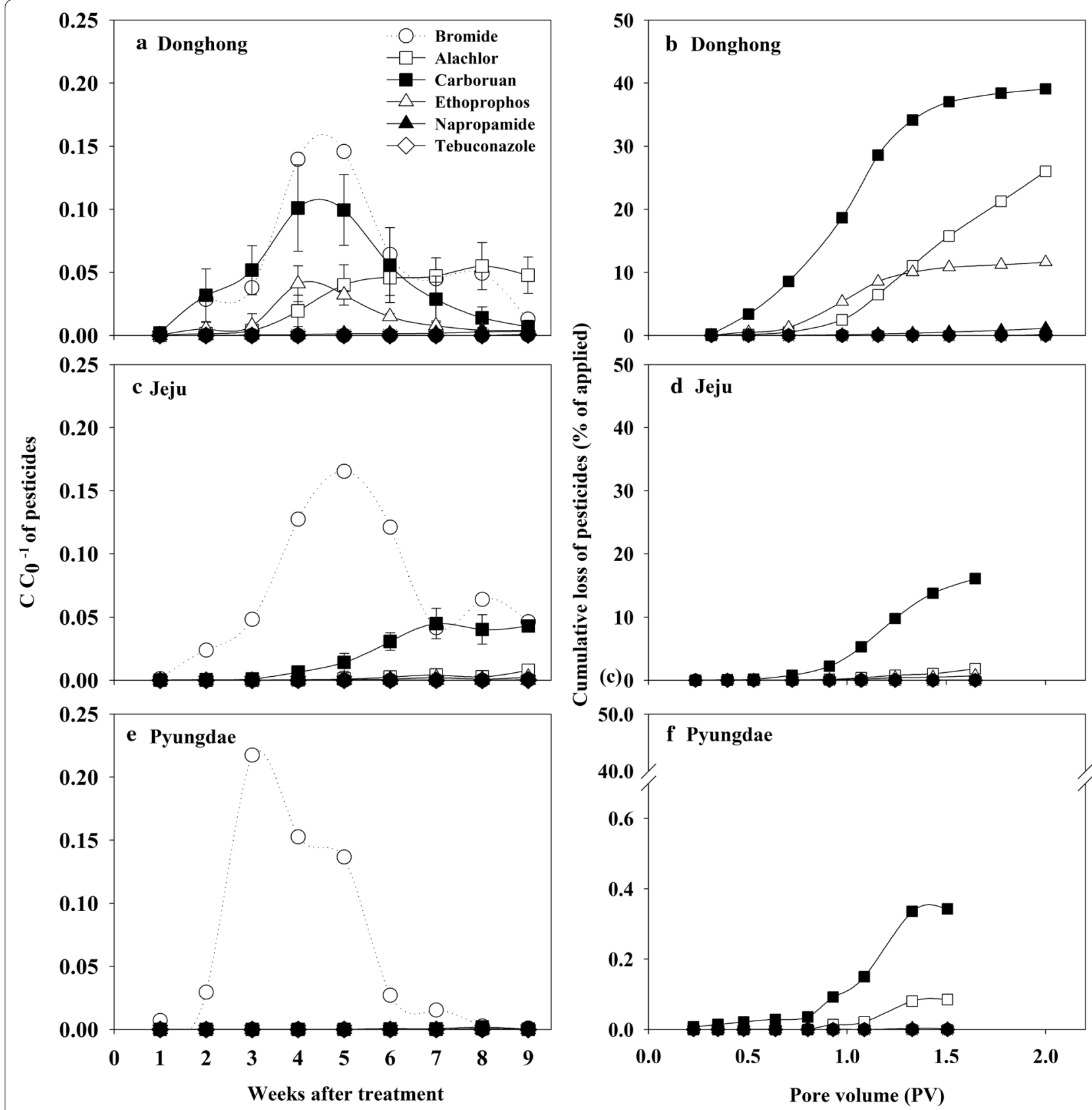

Fig. 6 Leaching pattern and cumulative loss of pesticides from the lysimeter with the soil series of Donghong, Jeju, and Pyungdae

pesticides in this study, the soil sorption experiment confirmed that it was mobile within only the Donghong and Jeju soils. Ethoprophos also leached from the Donghong and Jeju soils in the lysimeter experiment, and did not leach from the Pyungdae soil. Ethoprophos leached after 3 weeks from the Donghong soil, reached a peak leaching rate of $4.0 \%$ after 4 weeks, and then decreased. Ethoprophos showed a leaching rate of $0.2 \%$ from week seven to nine in the Jeju soil. The accumulated leaching rate was 11.6\% (2.00 PV) from the Donghong soil and 0.7\% (1.65 PV) from the Jeju soil. Napropamide and tebuconazole only showed mobility in the Donghong soil during the sorption experiment, and they were slightly leached from the Donghong soil during the lysimeter experiment. Napropamide leached after 4 weeks from the Donghong soil and reached a leaching rate of $0.3 \%$ after 9 weeks; the accumulated leaching by $2.0 \mathrm{PV}$ was $1.1 \%$. A low level $(0.1 \%)$ of Tebuconazole leached after 9 weeks from the 
Donghong soil, and the accumulated leaching rate was $0.09 \%$ by $2.0 \mathrm{PV}$. Similar results have been reported in previous studies, which demonstrated these three pesticides are not easy to leach from soils with higher organic carbon contents, such as the Pyungdae soil [1, 43-46].

An unexpected result from the lysimeter experiment was that ethoprophos and alachlor both showed a lower leaching than carbofuran, despite contrary predictions based on SOCA and solubility. In addition, alachlor, which was expected to be mobile within the Pyungdae soil, did not leach, whereas carbofuran leached, despite being predicted to be immobile. This could be the reason why ethoprophos and alachlor have a short half-life (approximately 14 days) that can be degraded. However, the half-life of pesticides will be different according to properties of soils and degradation mechanism. Actually, it was confirmed that alachlor was leached in other soils as well as carbofuran with a short half-life of 29 days was also leached in all studied soils. It indicates that the possibility of non-detection of both pesticides by degradation was very low. On the other hand, since the vapor pressure of ethoprophos and alachlor, were relatively high with 78 and $2.9 \mathrm{mPa}$, respectively. It is possible that these two pesticides were volatilized without leaching. Based on these results, the leachability of some pesticides with short half-life in Jeju Island soil could be underestimated. Volatilization can easily occur within the Pyungdae soil due to the large field capacity and porosity, and alachlor may not have leached despite the predictions of mobility. Conversely, carbofuran had a relatively low vapor pressure of $0.08 \mathrm{mPa}$ compared to the pesticides that leached, whereas its solubility was high (322 $\mathrm{mg} \mathrm{L}^{-1}$ ), which led to easy leaching in all experimental soils. In Donghong soil, carbofuran was found to be leached almost similar to bromide, a tracer, and moved rapidly with water. These results correspond with previous studies which confirmed that carbofuran easily leach from various types of soil [47, 48]. Based on these results, it was expected that carbofuran is easily to enter groundwater in soils with low organic carbon content such as Donghong soil. However, etridiazole was mobile within the Donghong soil with a low organic carbon content in the sorption experiment and was expected to leach in the Donghong soil when considering the SOCA (5.8) or solubility $\left(89 \mathrm{mg} \mathrm{L}^{-1}\right)$. However, etridiazole did not leach from any type of soil during the lysimeter experiment, which may be due to the highest vapor pressure of any studied pesticide (1430 mPa).

\section{Supplementary information}

Supplementary information accompanies this paper at https://doi. org/10.1186/s13765-020-00555-5.
Additional file 1: Table S1. Formulation type and trade name of pesticides sprayed on the lysimeter. Figure $\mathbf{S} \mathbf{1}$. Variations of distribution coefficients $\left(K_{d}\right)$ of soil samples (Donghong (Black circle), Jeju (Black downpointing triangle), and Pyungdae (Black square)) with organic carbon contents for the pesticides, classified as vulnerable. Figure $\mathbf{S 2}$. Variations of distribution coefficients $\left(\mathrm{K}_{\mathrm{d}}\right)$ of soil samples (Donghong (Black circle), Jeju (Black down-pointing triangle), and Pyungdae (Black square)) with organic carbon contents for the pesticides, classified as non-vulnerable.

\section{Acknowledgements}

This work was supported by Jeju Special Self-Governing Province and the Basic Science Research Program through the National Research Foundation of Korea (NRF) funded by the Ministry of Education (2016R1 A6A1A03012862).

\section{Author's Contributions}

WPP and KMC performed all the experimental work and data analyses as well as writing the manuscript. HNH designed the experiment, analyzed the data, and supervised the project. KHB and BJK edited and reviewed the manuscript. All authors read and approved the final manuscript.

\section{Competing interests}

The authors declare that they have no competing interests.

\section{Author details}

${ }^{1}$ Major of Plant Resources and Environment, Jeju National University, Jeju 63243, Republic of Korea. ${ }^{2}$ Plant and Environment R\&D Center, Samsung C\&T, Gunpo 15877, Republic of Korea. ${ }^{3}$ Department of Biotechnology, College of Applied Life Science (SARI), Jeju National University, Jeju 63243, Republic of Korea. ${ }^{4}$ Subtropical/Tropical Organism Gene Bank, Jeju National University, Jeju 63243, Republic of Korea. ${ }^{5}$ Department of Biological Sciences, California Baptist University, Riverside, CA 92504-3297, USA.

Received: 30 June 2020 Accepted: 20 October 2020

Published online: 04 November 2020

\section{References}

1. Boesten JJTI, van der Pas LJT (2000) Movement of water, bromide and the pesticides ethoprophos and bentazone in sandy soil: the Vredepeel data set. Agricu Water Manag 44:21-42

2. Jeju Special Self-Governing Province (JSSGP) (2016) White paper on environment. Jeju Special Self-Governing Province, Jeju

3. Jeju Special Self-Governing Province (JSSGP) (2018) Agriculture and food products. Korea, Jeju Special Self-Governing Province, p 50

4. Oh SS, Hyun HN, Moon DK (2000) Adsorption coefficients of eight pesticides for citrus orchard soils with different soil organic matter. Korean J Environ Agric 19:6-12

5. Chun SB, Yun IH, Kam SK (2019) Adsorption and leaching characteristics of ionic pesticides in the soils of Jeju Island, Korea. J Environ Sci Int 28:689-700

6. Karickhoff SW (1984) Organic pollutant sorption in aquatic systems. J Hydraul Eng 110:707-735

7. Wauchope RD, Yeh S, Linders J, Kloskowski R, Tanaka K, Rubin B, Katayama A, Kordel W, Gerstl Z, Lane M, Unsworth JB (2002) Pesticide soil sorption parameters: Theory, measurement, use, limitations and reliability. Pest Manag Sci 58:419-445

8. Lennartz B (1999) Variation of herbicide transport parameters within a single field and its relation to water flux and soil properties. Geoderma 91:327-345

9. Altfelder S, StreckT, Maraqa MA, Voice TC (2001) Nonequilibrium sorption of dimethylphthalate: Compatibility of batch and column techniques. Soil Sci Soc Am J 65:102-111

10. Cohen SZ, Wauchope RD, Klein AW, Eadsforth CV, Graney R (1995) Offsite transport of pesticides in water: Mathematical models of pesticide leaching and runoff. Pure Appl Chem 67:2109-2148

11. Aboukaled A, Alfaro A, Smith M (1982) Lysimeter. FAO irrigation and drainage papers, Food and agriculture organization of the United Nations (FAO) 
12. Francaviglia R, Di Carlo V, Aromolo R, Capri E (1996) Bromide and herbicides movement in field lysimeters: an application to assess groundwater vulnerability in the Mediterranean area. In: The Environmental Fate of Xenobiotics, Proceedings of the 10th Symposium Pesticide Chemistry, Castelnuovo Fogliani, Piacenza, Italy, 30 September-2 October pp 135-141

13. Zhu Y, Fox RH, Toth JD (2002) Leachate collection efficiency of zerotension pan and passive capillary fiberglass wick lysimeters. Soil Sci Soc Am J 66:37-43

14. Schmidt JP, Lin H (2008) Water and bromide recovery in wick and pan lysimeters under conventional and zero tillage. Commun. Soil Sci Plan 39:108-123

15. Boll J, Steenhuis TS, Selker JS (1992) Fiberglass wicks for sampling of water and solutes in the vadose zone. Soil Sci Soc Am J 56:701-707

16. Knutson JH, Lee SB, Zhang WQ, Selker JS (1993) Fiberglass wick preparation for use in passive capillary wick soil pore-water samplers. Soil Sci Soc Am J 57:1474-1476

17. Knutson JH, Selker JS (1994) Unsaturated hydraulic conductivities of fiberglass wicks and designing capillary wick pore-water samplers. Soil Sci Soc Am J 58:721-729

18. Oh SS, Hyun HN, Moon DK, Chung JB (2002) Estimation of pesticide leaching potential using GUS, RF and AF index in Cheju citrus orchard soils. Korean J Environ Agric 21:7-16

19. Hyun HN, Jang GM, Oh SS, Chung JB (2007) Evaluation of groundwater contamination potential of pesticides using groundwater ubiquity score in Jeju Island soils. Korean J Pestic Sci 11:144-153

20. Dusek J, Sanda M, Loo B, Ray C (2010) Field leaching of pesticides at five test sites in Hawaii: study description and results. Pest Manag Sci 66:596-611

21. Choi HM, Lee JY (2012) Changes of groundwater conditions on Jeju volcanic island, Korea: Implications for sustainable agriculture. Afr J Agric Res 7:647-661

22. Koh K, Park JB, Kang BR, Kim GP, Moon DC (2013) Volcanism in Jeju Island. J Geol Soc Korea 49:209-230

23. Mair A, Hagedorn B, Tillery S, El-Kadi Al, Westenbroek S, Ha K, Koh GW (2013) Temporal and spatial variability of groundwater recharge on Jeju Island, Korea. J Hydrol 501:213-226

24. Shin JS, George S (1988) Composition and genesis of volcanic ash soils in Jeju Island, I. Physico-chemical and macro-micromorphological properties. J Miner Soc Korea 1:32-39

25. Moon KH, Lim HC, Hyun HN (2007) Distribution of soil series in Jeju Island by proximity and altitude. Korean J Soil Sci Fert 40:221-228

26. National Academy of Agricultural Science (NAAS) (2014) Taxonomical Classification of Korean Soils. Suwon-si, Republic of Korea, Rural Development Administration

27. Song KC, Kang HJ (2019) Taxonomical classification and genesis of Hoesu series, new series in Jeju Island. Korean J Soil Sci Fert 52:40-50

28. Agricultural Sciences Institute (ASI) (1976) Cheju Do detailed soil map. Suwon-si, Republic of Korea, Rural Development Administration

29. Allison LE (1965) Organic carbon. In: Black CA, Evans DD, White JL, Enisminger LE, Clark FE (eds) Methods of Soil Analysis: Part 2-Chemical and Microbiological Properties, American Society of Agronomy: Madison. WI, USA, pp 1372-1378

30. Blake GR, Hartge KH (1986) Bulk density. In: Klute A (ed) Methods of Soil Analysis: Part 1_Physical and Mineral Methods, $2^{\text {nd }}$ edn. American Society of Agronomy - Soil Science Society America, Madison, WI, USA, pp 363-375

31. Blake GR, Hartge KH (1986) Particle density. In: Klute A (ed) Methods of Soil Analysis: Part 1_Physical and Mineral Methods, $2^{\text {nd }}$ edn. American Society of Agronomy_-Soil Science Society America, Madison, WI, USA, pp 377-382
32. Klute A, Dirksen C (1986) Hydraulic conductivity and diffusivity: Laboratory methods. In: Klute A (ed) Methods of Soil Analysis: Part 1-Physical and Mineral Methods, $2^{\text {nd }}$ edn. American Society of Agronomy-Soil Science Society America, Madison, WI, USA, pp 687-734

33. IUPAC (2020) https://sitem.herts.ac.uk/aeru/iupac/search.htm. Accessed 17 August 2020

34. Jabro JD, Lotes EG, Simmons KE, Baker DE (1991) A field study of macropore flow under saturated conditions using a bromide tracer. J Soil Water Conserv 46:376-380

35. Jemison JM Jr, Jabro JD, Fox RH (1994) Evaluation of LEACHEM: I. Simulation of drainage, bromide leaching and corn bromide uptake. Agron J 86:843-851

36. Brown CD, Hollis JM, Bettinson RJ, Walker A (2000) Leaching of pesticides and a bromide tracer through lysimeters from five contrasting soils. Pest Manag Sci 56:83-93

37. Park WP, Kang HJ (2019) Study on soil erosion and physical characteristics of Jeju volcanic ash soils under a rainfall simulator condition. Korean J Soil Sci Fert 52:60-69

38. Hall KE, Ray C, Ki SJ, Spokas KA, Koskinen WC (2015) Pesticide sorption and leaching potential on three Hawaiian soils. J Environ Manage 159:227-234

39. Kelly BP, Pomes ML (1998) Preferential flow and transport of nitrate and bromide in claypan soil. Groundwater 36:484-494

40. Piwowarczyk A, Peng X, Richards KG, Holden NM (2010) A laboratory lysimeter for pesticide transport with controlled boundary conditions. In: Symposium 3.2. 2 Improved water and soil management using lysimeters, Proceedings of the 19th World Congress of Soil Science: Soil solutions for a changing world, Brisbane, Australia, 1-6 August 2010; International Union of Soil Sciences (IUSS), c/o Institut für Bodenforschung, Universität für Bodenkultur, pp 1-4

41. Johnson RM, Pepperman AB (1996) Leaching of alachlor from alginateencapsulated controlled-release formulations. Pestic Sci 48:157-164

42. Lerch RN, Blanchard PE (2003) Watershed vulnerability to herbicide transport in northern Missouri and southern lowa streams. Environ Sci Technol 37:5518-5527

43. Vanclooster M, Ducheyne S, Dust M, Vereecken H (2000) Evaluation of pesticide dynamics of the WAVE-model. Agric Water Manag 44:371-388

44. Williams CF, Letey J, Farmer WJ (2006) Estimating the potential for facilitated transport of napropamide by dissolved organic matter. Soil Sci Soc Am J 70:24-30

45. Navarro S, Fenoll J, Vela N, Ruiz E, Navarro G (2009) Photocatalytic degradation of eight pesticides in leaching water by use of $\mathrm{ZnO}$ under natural sunlight. J Hazar Materi 172:1303-1310

46. Dousset S, Thévenot M, Schrack D, Gouy V, Carluer N (2010) Effect of grass cover on water and pesticide transport through undisturbed soil columns, comparison with field study (Morcille watershed, Beaujolais). Environ Pollu 158:2446-2453

47. Johnson WG, Lavy TL (1995) Persistence of carbofuran and molinate in flooded rice culture. J Environ Qual 24:487-493

48. Chilton PJ, Lawrence AR, Stuart ME (1998) Pesticides in groundwater: some preliminary results from recent research in temperate and tropical environment. In: Mather J, Banks D, Dumpleton S, Fermor M (eds) Groundwater Contaminants and their migration, Geological Society, London, Special Publications, 128:333-345

\section{Publisher's Note}

Springer Nature remains neutral with regard to jurisdictional claims in published maps and institutional affiliations. 